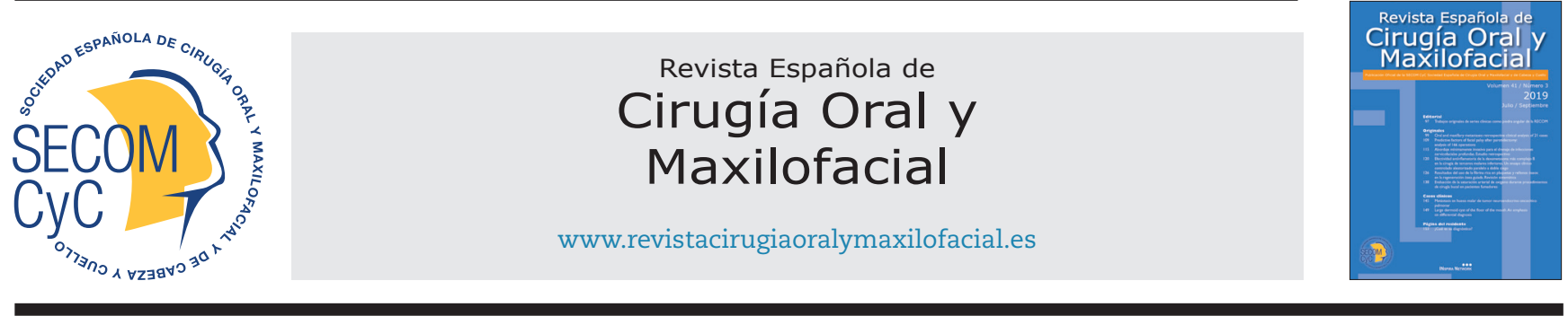

\title{
Original
}

\section{Oral and maxillary metastases: retrospective clinical analysis of 21 cases}

\section{Carlos Prola,b,c, Sara Ruiz-Osléd, Sefora Malaetxebarría ${ }^{e}$, Ainara Doladof, Olga M. del Hoyog y Luis Barbier ${ }^{a, b, c}$}

${ }^{a}$ Cirugía Maxilofacial Department. Cruces University Hospital, Barakaldo, Spain. ${ }^{b}$ Cirugía Maxilofacial Group. Biocruces Bizkaia Research Institute, Barakaldo, Spain. 'Estomatología I Department. University of the Basque Country UPV/EHU, Leioa, Spain. ${ }^{\mathrm{d} U r o l o g i ́ a}$ Department. Cruces University Hospital, Barakaldo, Spain. ${ }^{e}$ Anatomía Patológica Department. Cruces University Hospital, Barakaldo,

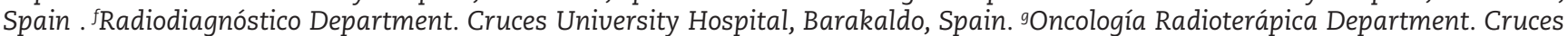
University Hospital, Barakaldo, Spain

A R T I C L E I N F O

\section{Article history:}

Received 4 march 2019

Accepted 5 july 2019

Keywords:

Jaw, metastases, mouth, chemotherapy, radiotherapy, oncologic surgery.

\begin{abstract}
A B S T R A C T
Objective: Retrospective descriptive study of 21 oral soft tissue and/or maxillary bone metastatic cases.

Materials and methods: Hospital records of our own department are reviewed for a 12-year period. Lymphoproliferative diseases, skin metastases, salivary glands, other craniofacial bones and cervical lymph-nodes are excluded. Epidemiologic, personal health, clinical, treatment and follow-up data are recollected and analysed in frequency statistics.

Results: Male:Female ratio is 1.3:1, year-old range 52-82 and ethnic group $100 \%$ white-caucasian. $19.0 \%$ have carcinogenic occupational exposure, $52.4 \%$ tobacco abuse, $61.9 \%$ some kind of alcohol use, $57.1 \%$ cardiovascular risk, $19.0 \%$ cardiologic records, $28.6 \%$ pulmonary, $19.0 \%$ gastrointestinal, $19.0 \%$ endocrine, $14.3 \%$ genitourinary, $9.5 \%$ other primary malignancy and $23.8 \%$ a first-degree relative with a neoplasm. $33.3 \%$ patients have taken osteonecrosisrelated drugs or received craniofacial radiotherapy.

Metastasis is the debut in 7 patients while it corresponds to infirmity progression in 14 . The chief reason for consultation is a mass. 8 lesions affect soft tissue and 13 the bone. $81.0 \%$ have epithelial neoplasm lineages. The organ of origin is: $23.8 \%$ lung, 23.8 breast, $23.8 \%$ kidney, $9.5 \%$ skin, $9.5 \%$ soft parts, $4.8 \%$ prostate and $4.8 \%$ thyroid. $100 \%$ have other location metastases. $14.3 \%$ patients undergo surgery, $38.1 \%$ receive radiotherapy, $47.6 \%$ chemo- or targeted therapy, and $28.6 \%$ symptomatic treatment. After a 1-124 months range of followup, 17 patients die and 4 are alive.
\end{abstract}

${ }^{*}$ Corresponding author:

E-mail address: drprolteijeiro@gmail.com (Carlos Prol Teijeiro).

DOI: 10.20986/recom.2019.1058/2019

1130-0558/@ 2019 SECOM. Publicado por Inspira Network. Este es un artículo Open Access bajo la licencia CC BY-NC-ND (http:// creativecommons.org/licenses/by-nc-nd/4.0/). 
Conclusions: Craniomaxillofacial metastases, usually with multiple visceral or axial skeleton lesions, have an ominous prognosis. Multidisciplinary management could benefit the patient status and lead to more favourable outcomes. There are exceptional cases of long-term survival.

\section{Metástasis orales y maxilares: análisis clínico retrospectivo de 21 casos}

\section{R E S U M E N}

Keywords:

Mandíbula, metástasis, boca, quimioterapia, radioterapia, cirugía oncológica.
Objetivo: Estudio descriptivo retrospectivo de 21 casos de metástasis en tejidos blandos orales y/o huesos maxilares.

Material y métodos: Revisión a 12 años de actas de nuestro departamento, excluyendo procesos linfoproliferativos, metástasis cutáneas, glándulas salivales, otros huesos craneofaciales y ganglios cervicales. Se recopilan datos epidemiológicos, antecedentes, clínicos, tratamiento y seguimiento, y analizan mediante estadísticos de frecuencia.

Resultados: La proporción varón:mujer es 1,3:1, entre 52-82 años y todos de etnia blancocaucásica. El 19,0 \% tiene exposición laboral carcinógena, el 52,4 \% tabaquismo, el 61,9 \% consumo de alcohol, el 57,1 \% riesgo cardiovascular, el 19,0 \% patología cardiaca, el 28,6 \% pulmonar, el $19 \%$ gastrointestinal, el $19 \%$ endocrina, el 14,3\% genitourinaria, el 9,5 \% otro tumor maligno primario y el 23,8 \% un familiar de primer grado con una neoplasia, el 33,3\% ha tomado fármacos asociados a osteonecrosis o recibido radioterapia craneofacial.

Siete pacientes debutan con la metástasis y 14 como progresión de neoplasia conocida. El motivo de consulta principal es una masa. Ocho lesiones afectan a tejidos blandos y 13 al hueso. El 81 \% son tumores de estirpe epitelial. El origen es: 23,8 \% pulmón, 23,8 \% mama, 23,8 \% renal, 9,5 \% piel, 9,5 \% partes blandas, 4,8 \% próstata y 4,8 \% tiroides. El $100 \%$ tiene metástasis en otras localizaciones. El 14,3\% pacientes son tratados con cirugía, el 38,1 \% con radioterapia, el $47,6 \%$ con quimio- o terapia dirigida, y el $28,6 \%$ con tratamiento sintomático. 17 pacientes fallecidos y 4 vivos con rango 1-124 meses de seguimiento.

Conclusiones: Las metástasis craneomaxilofaciales, habitualmente con múltiples lesiones viscerales o en esqueleto axial, tienen pronóstico infausto. El manejo multidisciplinar podría beneficiar el estado basal del paciente y llevar a mejores resultados. Existen casos excepcionales de supervivencia a largo plazo.

\section{INTRODUCTION}

Less than $3 \%$ of malignant oral and maxillary lesions are metastases. Primary infraclavicular solid tumours that most commonly spread to head \& neck are from epithelial strain and lung or breast origin. Most frequently affected regions are the attached gingiva in regard to oral soft tissues, and the mandible in the molar area in regard to bones. Typical reasons for consultation are an exophytic nodule or mass, with bleeding tendency, inflammation, pain or sensory disturbance ${ }^{1,2}$.

\section{MATERIAL AND METHODS}

Our work centre is a tertiary level hospital, which covers about a 385.000 population area in relation to Oral \& Maxillofacial public assistance. Every patient with a malignant tumour diagnosis in our department is included in a clinical session of our own and a multidisciplinary one. A complete review of the session records is performed, from January 2003 to December 2018. This study is retrospective of a standard diagnosis and treatment praxis, so institutional review board approval was exempt. 21 cases of metastatic lesions located in soft tissue of the mouth and/or maxillary bones are found. Excluding criteria are: less than 18-year-old; metastases located in the skin, salivary glands, other craniofacial bones and exclusive cervical lymph-node affectation; lymphoproliferative disorders; and not-known origin.

Epidemiologic data, general potentially carcinogenic and personal health records (PHR), first-degree relative oncologic processes, current disease, neoplasm strain and origin, treatment and follow-up data are collected.

In relation to toxic habits, tobacco abuse is considered in three levels: less or equal than 5 pack-years (+), between more than 5 and less or equal than 15 pack-years $(++)$, and more than 15 pack-years $(+++)$. In similar way, alcohol use is codified in other three levels: less or equal than 2 alcohol units/ day (+), between more than 2 and less or equal than 8 units/ day $(++)$, and more than 9 units/day $(+++)$. In relation to PHR, usual cardiovascular risk factors are considered (hypertension, type 2 diabetes, hyperlipidemia). Cardiologic records include arrhythmias, ischemic heart disease, valvulopathies and other miocardiopathies. Pulmonary records cover chronic obstructive pulmonary disease, asthma, obstructive sleep apnoea, lung infection sequels (basically tuberculosis) and other fibrous lung disorders. Gastrointestinal records include 
oesophageal reflux disease, peptic ulcer, diverticles, benign adenomas, and infectious, alcoholic or autoimmune hepatic diseases. Endocrine records cover goitre and other thyroid affections, osteoporosis and other metabolic bone conditions. Genitourinary records include hyperuricemia, chronic renal failure and other nephropathies, endometriosis and ovary cysts. Even other general background data could be collected, it was not considered for the present study to not overburden it with irrelevant information.

Furthermore, any treatment which involves osteonecrosis as an adverse effect was specifically collected.

A retrospective descriptive analysis of frequencies is carried out with the Microsoft Excel ${ }^{\circledR} 2007$ software.

\section{RESULTS}

There are 17 unreported cases while case number 11, 12,13 and 20 have been published before as case-reports ${ }^{3,4}$. 12 patients are males and 9 females, with mean age of 62.9 years-old, 52-82 range. All of them are white-caucasians. In relation to PHR, $19.0 \%$ of the patients have a potentially carcinogenic occupational exposure, every one of them from lung origin. $52.4 \%$ refer some kind of tobacco abuse, $61.9 \%$ alcohol use and no one other substance abuse. $9.5 \%$ have some drugrelated allergy reported. One or more cardiovascular risk factor are known in $57.1 \%$, cardiologic records in $19.0 \%$, pulmonary in $28.6 \%$, gastrointestinal in $19.0 \%$, endocrine in $19.0 \%$ and genitourinary in $14.3 \% .9 .5 \%$ suffered other malignant tumour different from the current one, and $23.8 \%$ have a first-degree relative with a neoplasm. $33.3 \%$ patients, due to oncologic process, have received treatment with bisphosphonates or other osteonecrosis-related drugs, or received craniofacial radiotherapy (Table I).

The metastasis is the malignancy debut in 7 patients. It corresponds to infirmity progression in 14, only 2 of them without previous stage IV, with range of 1-252 months from the first oncologic diagnosis. The reason of consultation is a mass in $66.7 \%$, nodule $14.2 \%$, temporo-mandibular joint dysfunction $4.8 \%$ and scheduled examination finding (periostitis in computed tomography and high uptake in scintigraphy) $9.5 \%$. Localization is soft tissue in 8 patients and the maxilla, the mandible or both in 13 (Figure 1). $81.0 \%$ neoplasms are from epithelial lineage, $9.5 \%$ melanoma and $9.5 \%$ sarcoma. $23.8 \%$ of the tumours originated in the lung, $23.8 \%$ breast, $23.8 \%$ kidney, $9.5 \%$ skin, $9.5 \%$ soft parts, $4.8 \%$ prostate and 4.8 thyroid (Figure 2). Oncogene studies, available in 4 patients, reveal 2 ERRB2 positive cases, both of them from breast origin. All of the patients have at some point of the evolution metastases in other localizations, highlighting bones (66.7\%) and lungs (56.3\%), excluding the primary ones of these regions (Table II).

The maxillofacial metastasis treatment is surgery in $14.3 \%$, radiotherapy $38.1 \%$, chemo-/immune-/biological therapy in $47.6 \%$ and just symptomatic treatment in $28.6 \%$, which coincides with those patients who die before less than 5 months after the metastasis diagnosis. Follow-up ranges from 1 to 124 months. 17 patients die, 2 of the living have stable infirmity, 1 is in progression and 1 has no evidence of disease. Taking in account those patients who still are alive, the main survival is 23.0 months (Table II).

\section{DISCUSSION}

Metastasis is the main cause of morbidity and mortality in most oncologic patients. Almost any malignant tumour could disseminate to the head and neck. Most common primary sites differ between genders and geographic area, mainly between Eastern and Western series. This fact may reflect differences in the prevalence of primary tumours and indirectly oncologic risk factors, genetics and lifestyles. Most reported cases in the literature are from United States of America, inserting an important geographic bias ${ }^{5,6}$.

A literature review of recent similar single/double institution case-series as ours is performed, with more than 15 cases and a 10-year period minimum (Table III) ${ }^{5,7-19}$. Inclusion and exclusion criteria are very heterogeneous. Two series only focus in one region ${ }^{7,15}$. Several of them consider other maxillofacial regions for metastasis target, such as the parotid gland, head \& neck skin and cervical lymph-nodes, apart from oral soft tissues and jaws. We reported metastases from solid tumours including melanocytic origin, while other studies include lymphoproliferative disorders and not-known primary cancer localization neither histology. Men are more prevalent than women in all the series except one from Brazil ${ }^{14}$. Mean age is between the $5^{\text {th }}$ and $7^{\text {th }}$ decades, but oral metastases could develop at any age. Some studies consider for their analysis children versus adults, because of radically different lineage, origin and better prognosis in the first ones ${ }^{17}$. Most common tissue lineage of solid tumours is epithelial, carcinomas or and adenocarcinomas, in all the series. Regarding the metastasis source, it is lung or breast in Western countries while it stands out lung or liver in the Eastern ones. Except ours and other one from France ${ }^{15}$, mean survival of solid tumours is equal or less than 16 months in all the series. One of the main differences of our study from all the others is the inclusion of detailed background of the patients.

Tumour cells have unique heterogeneous and plasticity properties due to innate and acquired accumulated mutations. Before a metastatic lesion is established, sequential steps happen, known as the invasion-metastasis cascade. They are: penetration through the extracellular matrix (ECM) from the primary tumour, intravasation into the vessels, circulation until settlement in the microvasculature target organ, extravasation, invasion of the underlying EMC, and angiogenesis processes. Highly perfused organs, such as the lung capillary network, are usual locations where circulating tumour cells could be passively trapped. Inflammatory microenviroment could help to engraft and proliferate. Bone marrow with its stromal cells, chemokines, integrins and other pro-growing molecules, is also a favourable target for metastasis. Bone remodelling, by OPG/RANK/RANKL pathways and by osteoclasts and osteoblasts cells, is corrupted, developing a mix of osteolytic, usually predominant, and osteoblastic elements in metastatic lesions $s^{1,2,7,20}$.

Many cases of soft tissues and bone craniomaxillofacial metastasis happen in patients with widespread disease, probably result of secondary spread from other metastasis, especially located in the lungs. Other proposed theories, especially in cases where the head \& neck metastases is the first indication of occult malignancy, are that circulating tumour 


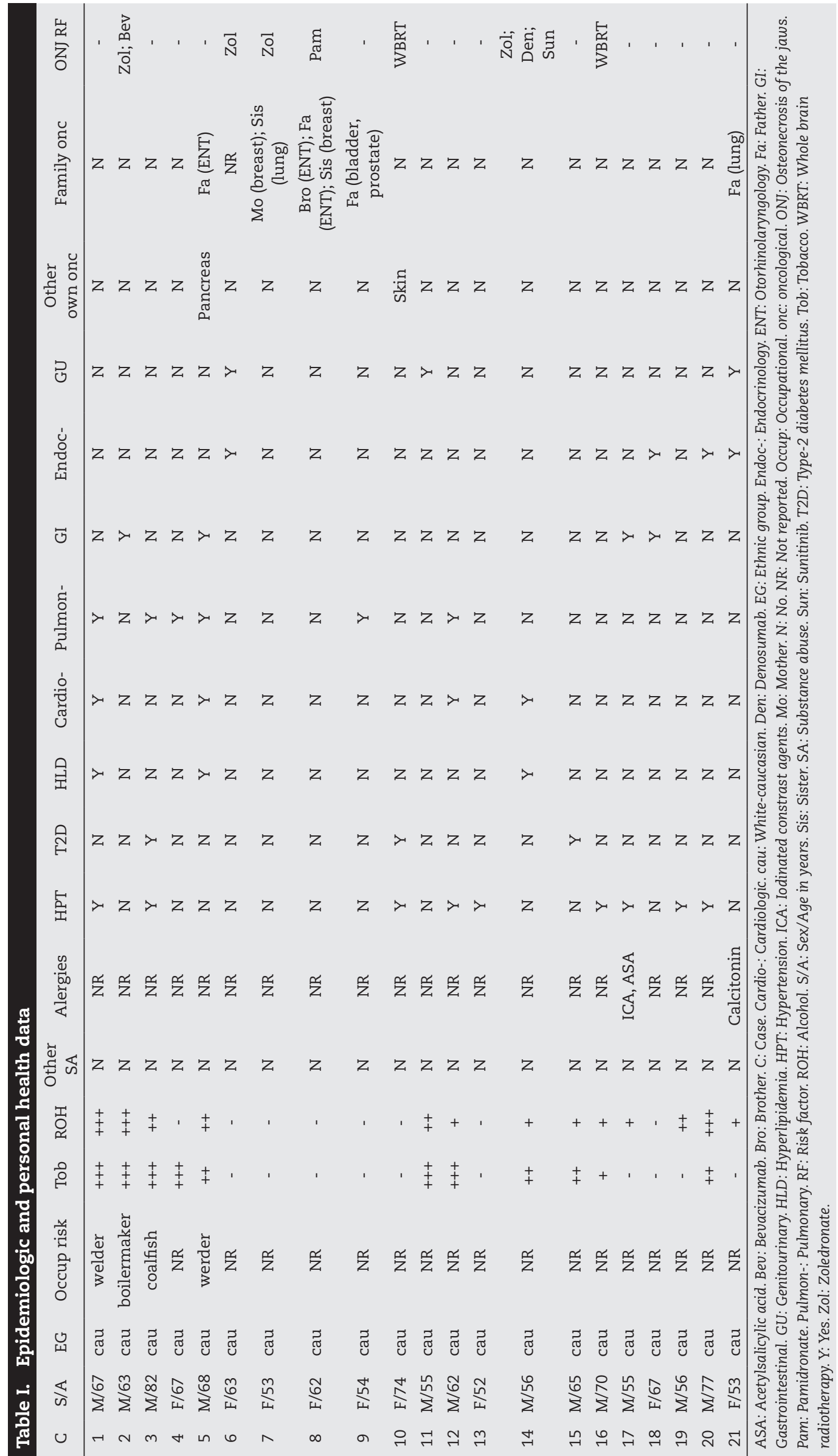



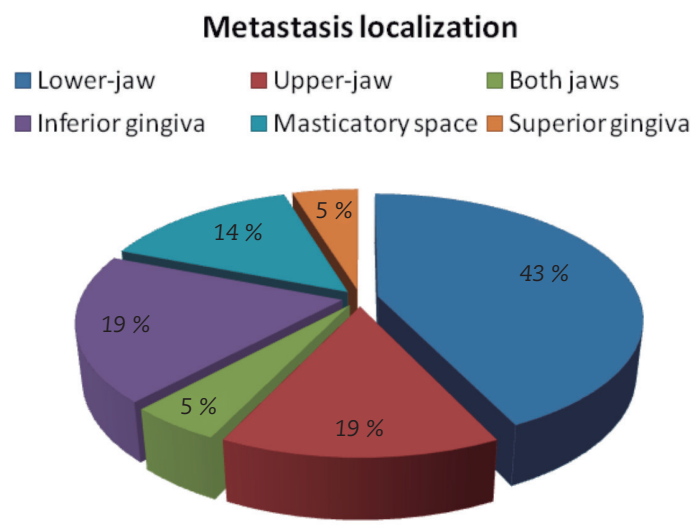

Figure 1. Oral and maxillary bone metastases localization.

cells bypass the lung circulation through the valveless vertebral venous plexux. Furthermore, because of the tumour cells plasticity, they could spread through arteriovenous shunts ${ }^{1,3}$.

Jawbones are slightly more common affected than softtissues. The mandible in molar area, premolar and the angle/ ramus are the most frequent localizations. Pathogenesis is not clear, but there are a haematopoietic marrow remainder located in the posterior part of the mandible in adults ${ }^{1,4}$. In relation to soft tissues, the attached gingiva and tongue are common affected sites, considering the chronic inflammation a co-factor in the attraction of metastatic cells $s^{1,20}$.

Main clinical differential diagnosis of metastatic lesions is with primary oral squamous cell carcinoma, benign tumours and reactive lesions such as pyogenic granuloma or gigantic epulis. They typically present as big masses with local inflammation which could infiltrate, even ulcerate skin; and they have bleeding tendency, especially of renal and hepatic origin. Occasionally, symptoms are a bit confusing such us TMJ dysfunction or numbness, known as numb chin syndrome, and the diagnosis is delayed because of deviated attention to minor stomatognathic processes. Incidental finding of asymptomatic lesions in scheduled $\mathrm{x}$-ray explorations is a possibility too ${ }^{1,3,16,21}$.

Histological malignancy morphology is not definitive of metastasis, especially complex in low differentiated salivary gland tumours. The basic inmunohistochemical (IHC) panel usually include carcinoma (keratins, p53), melanoma (S-100), sarcoma (vimentin) and lymphoma (CD45) markers (Figure 3). Even with additional IHC and molecular techniques to discern the origin, sometimes the primary site remains obscure ${ }^{1}$. Intraoral located malignant melanoma lesions are sometimes very troublesome to discern the primary site, which could even present spontaneous regression ${ }^{22}$.

The typical radiological appearance of metastatic lesions is a huge infiltrating, and destructive lesion, with poorly defined margins, central necrosis, and contrast enhancement (Figure 4). However, no pathognomonic image exists and any possibility is available. Bone lesion patrons tend to be osteolytic but also small osteoblastic areas could be appreciated in most of them ${ }^{6,23}$. It could be difficult to differentiate from osteonecrosis, inasmuch as a lot of patients have radiotherapy or associated drugs uptake (biphosphonates, RANKL inhibitors, VEGF inhibitors) background. This situation is more troublesome in cases
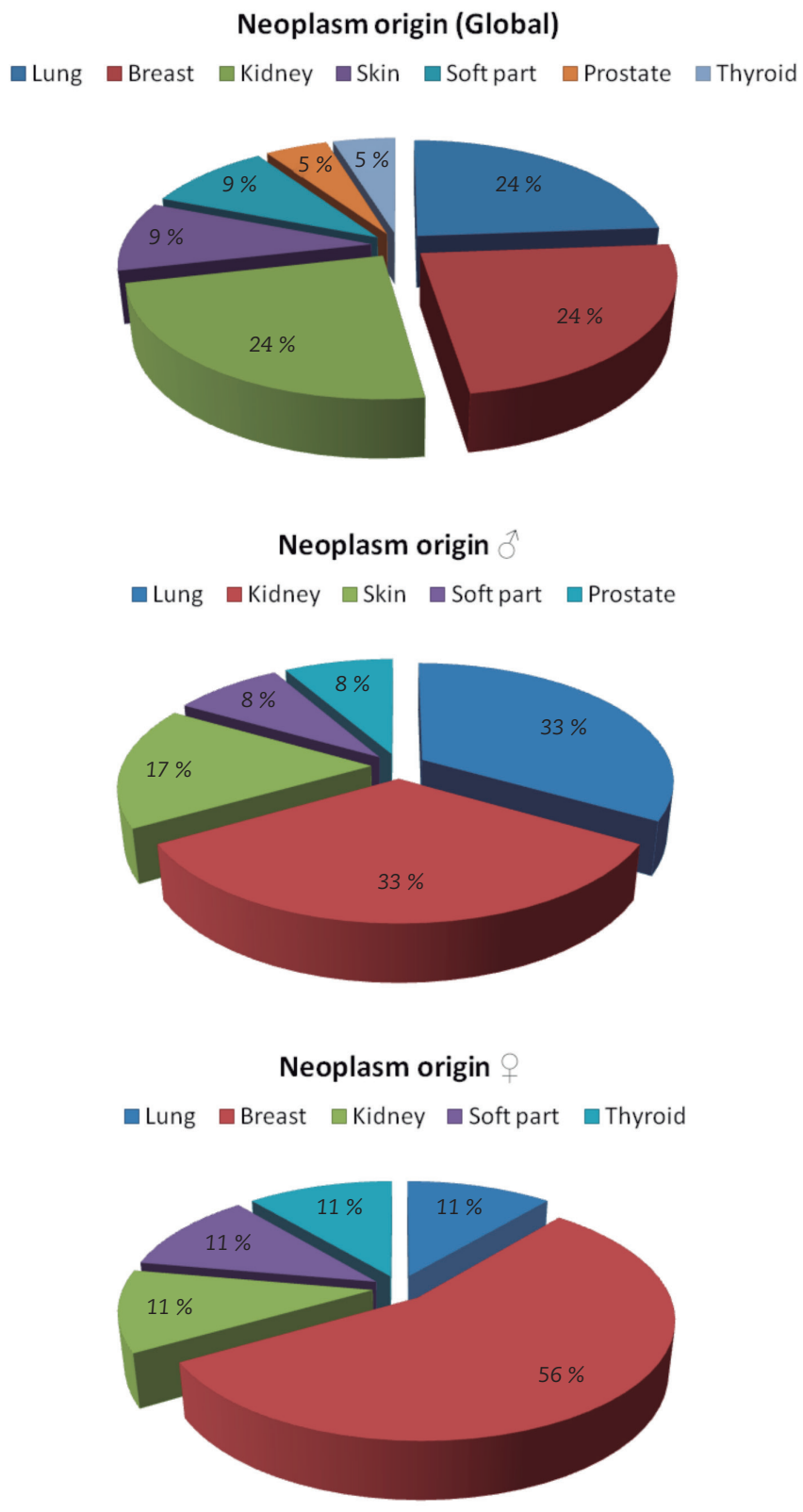

Figure 2. Primary neoplasm origin, global and stratified by sex.

without soft tissue mass. Given high suspicion and repeatedly negative biopsies, or region of difficult access such as TMJ, positron emission topographies could help to discern in favour of metastasis, as long as osteonecrosis is not in the active infection phase (Figure 5). In addition, the evolution and non-response to osteonecrosis treatment protocols will define the situation ${ }^{24,25}$.

Management of head \& neck metastatic tumours should be multidisciplinary and individualized to each patient. Main parameters of therapy are general health condition, type and localization of the primary tumour and metastasis. Surgery, radiotherapy and systemic treatment are possible, being the palliative care the need of the hour result of the poor overall prognosis. Average survival rate in craniomaxillofacial dissemination is less than 1 year in most large case-series ${ }^{1,2,6,8}$. 


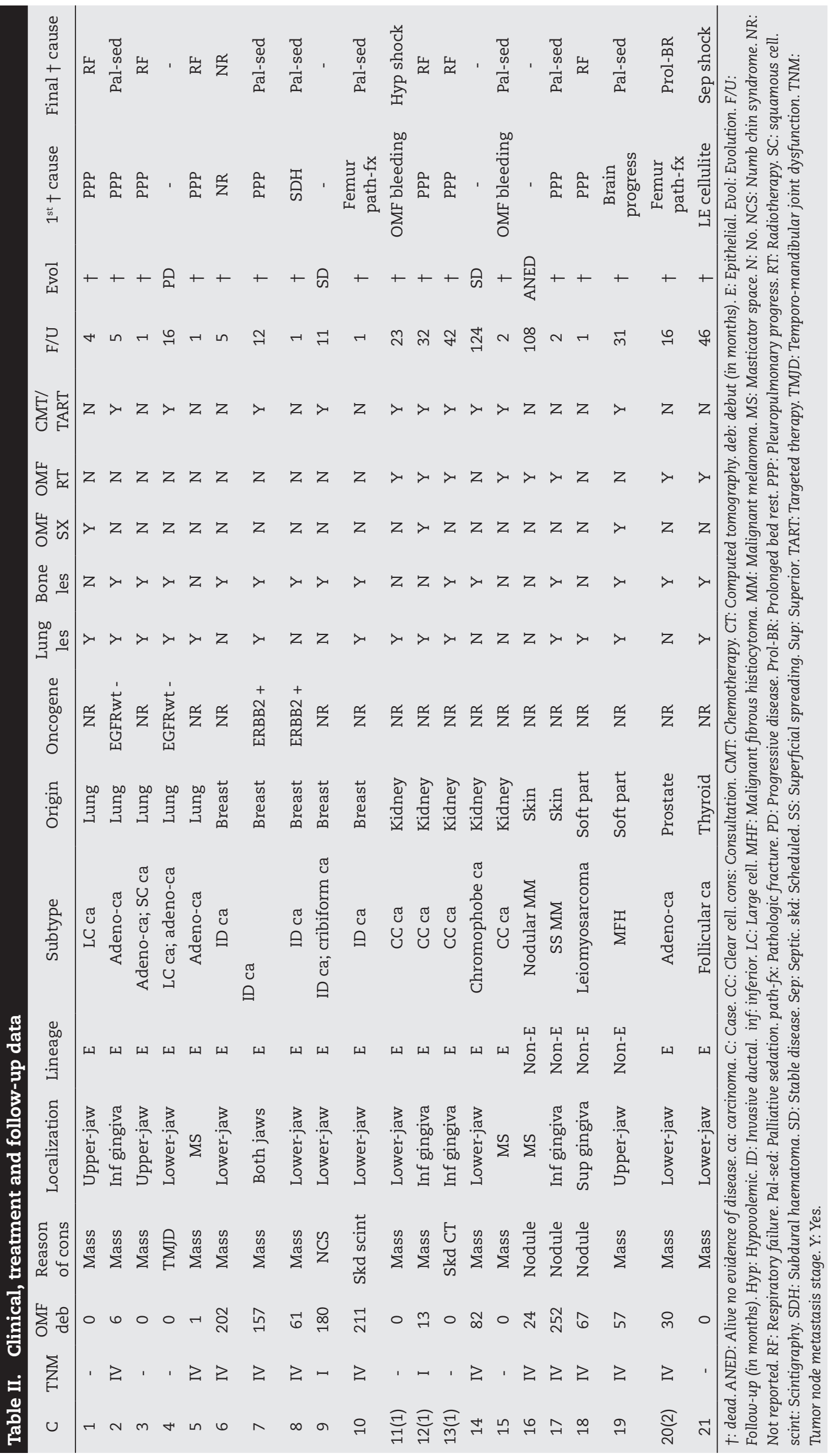




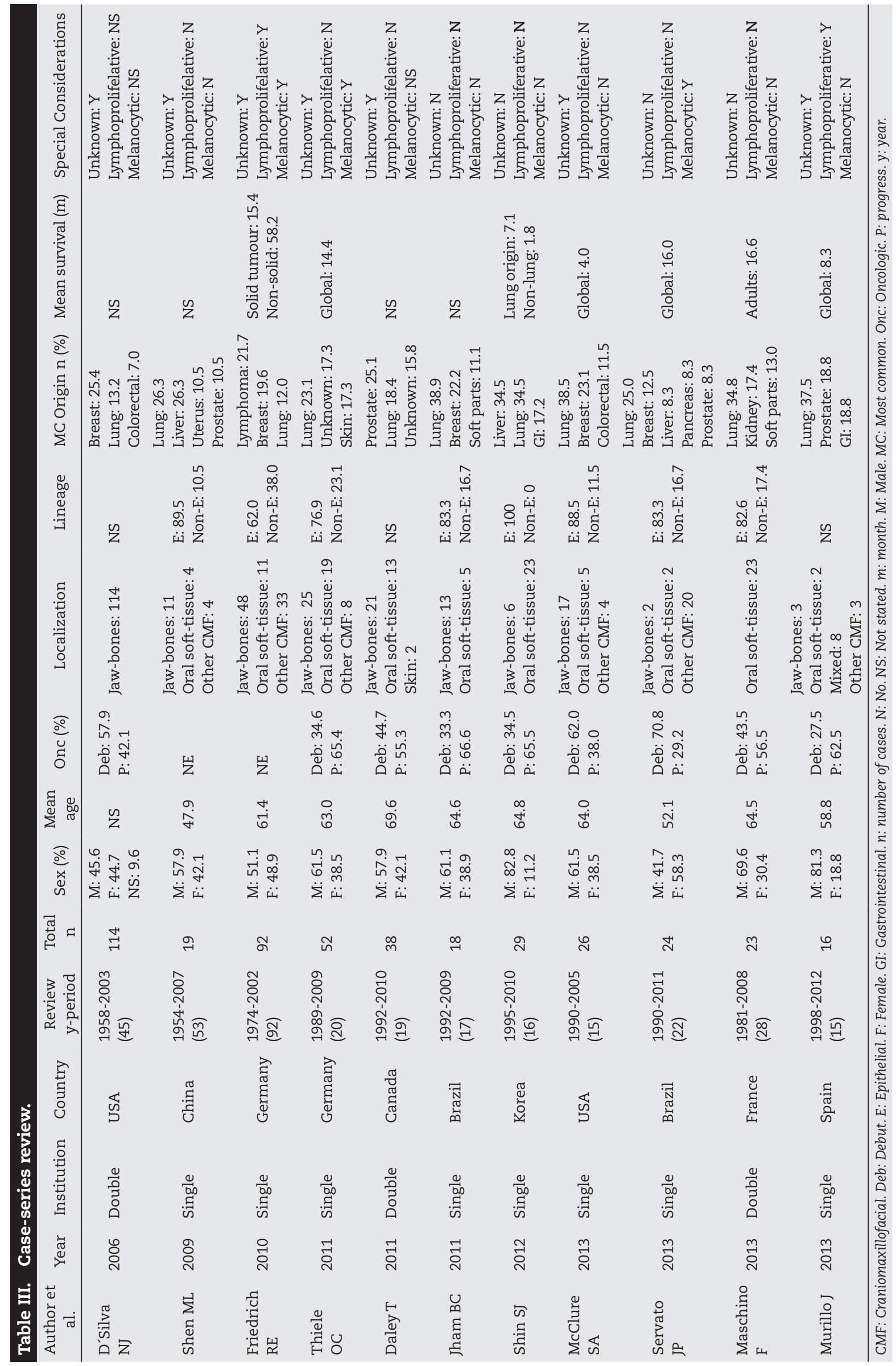




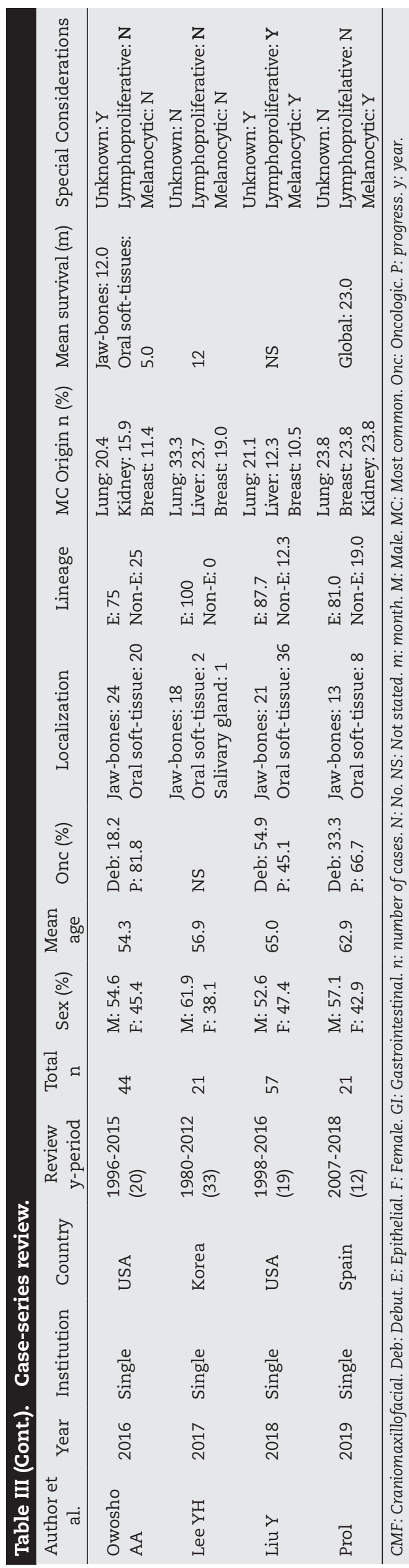

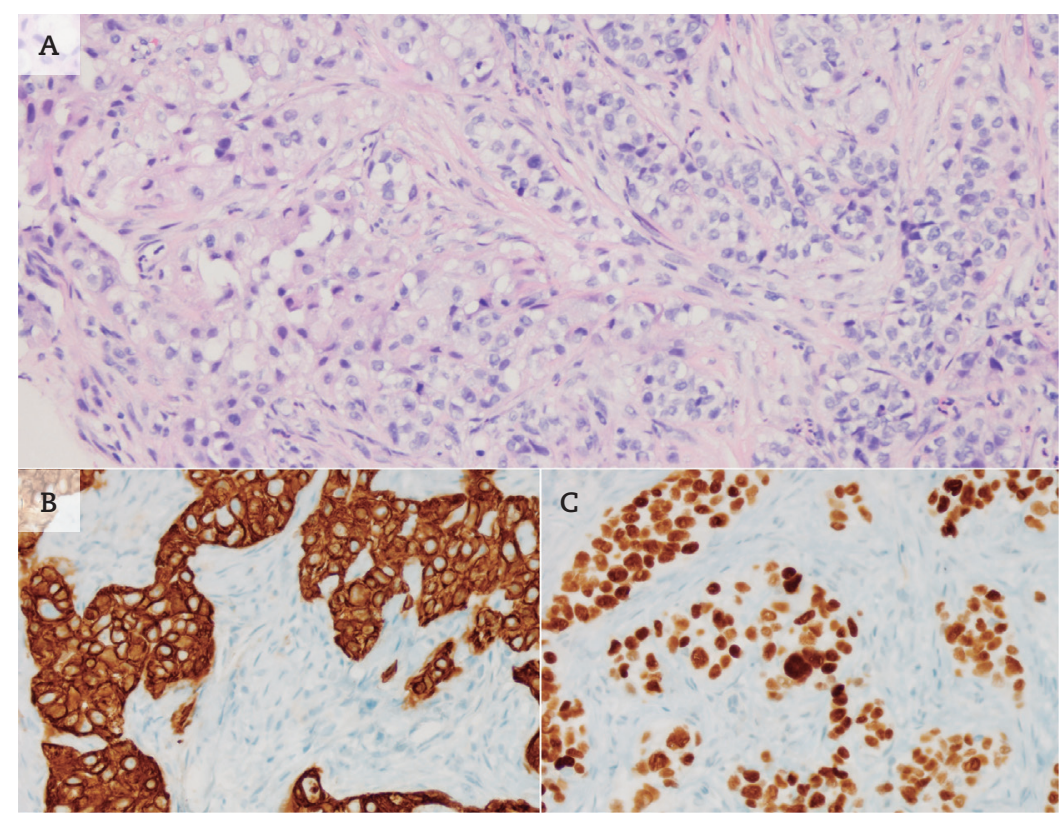

Figure 3. Case 2. Lung adenocarcinoma metastasis. Fibrous connective tissue extensively infiltrated by atypical cell solid nests. Pallid eosinophilic and slightly vacuolated cytoplasm, irregular nuclei with vesiculated chromatin and prominent nucleoli. A) 200x Hematoxilin \& Eosin. B) 400x CK7+. C) 400x TTF-1+.
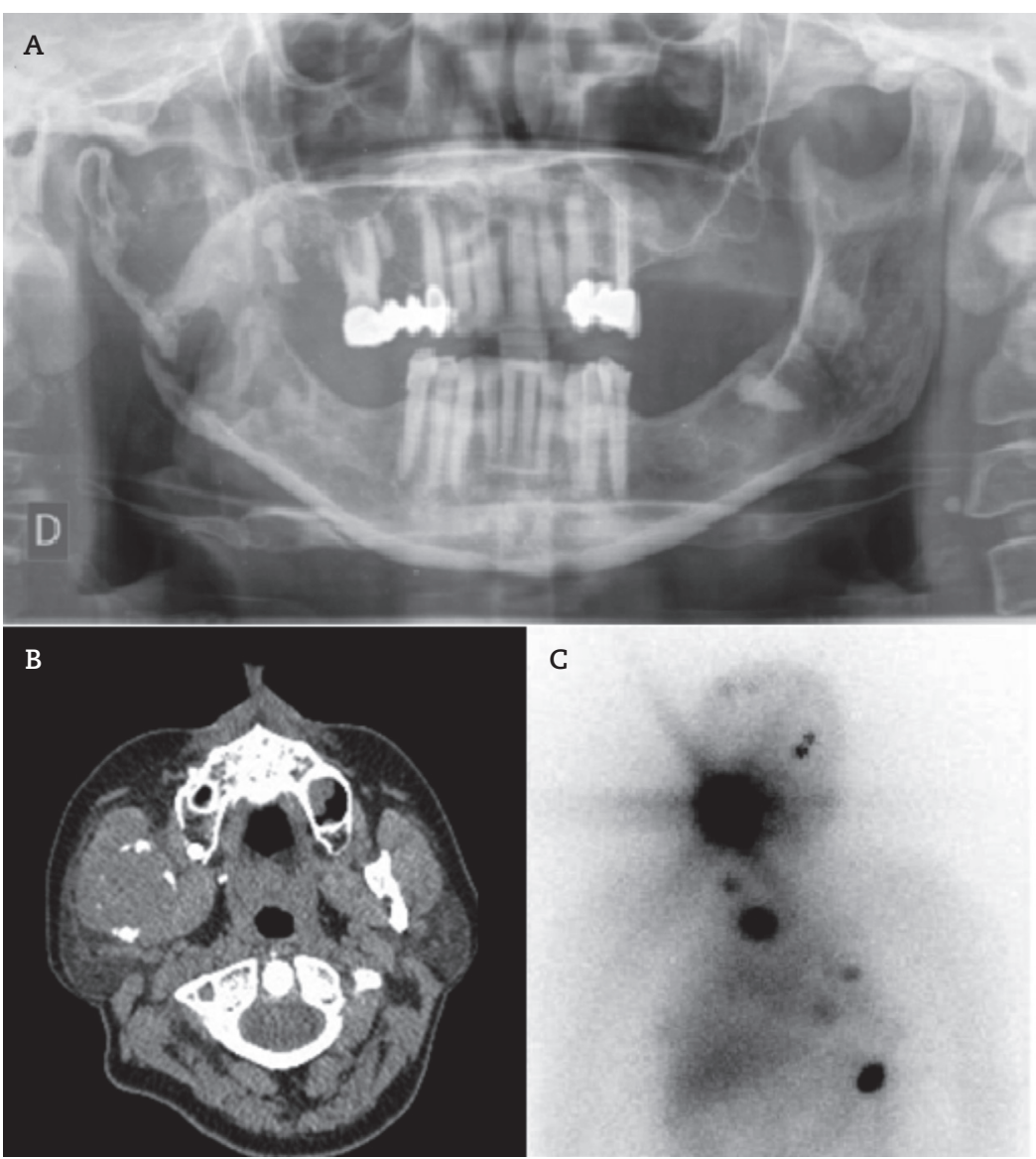

Figure 4. Case 21. Thyroid follicular carcinoma metastasis. Solid litic expansive lesion involving the right mandible ramus and condyle. A) Pantomography. B) Computed tomography axial slice. C). Iodine-131 scintigraphy frontal view. 

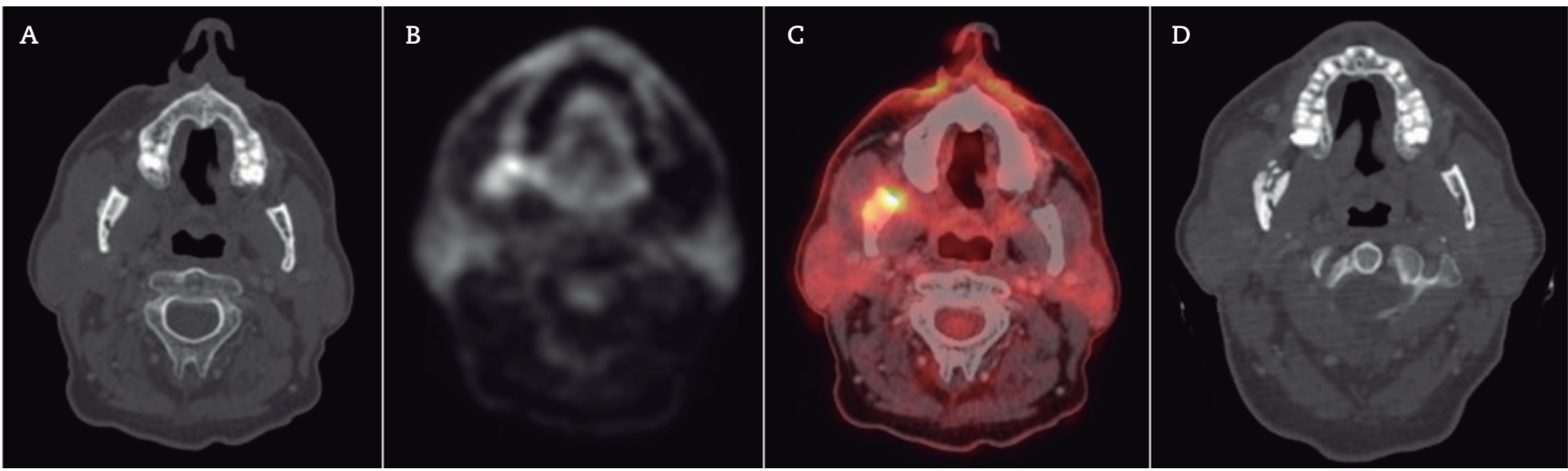

Figure 5. Case 14. Renal cromophobe carcinoma metastases. A-C) Fluordeoxiglucose-18 positron emission tomography. Rigth mandibule ramus periosteum inflammation, especially pronounced in the vestibular cortical, with high uptake (6.6 SUV $\mathrm{max})$.

D) Computed tomography 9 months later. Progression to a mixed osteolitic and osteoblastic lesion.

\section{CONCLUSIONS}

Craniomaxillofacial metastases are usually late complications of advanced neoplasm with multiple visceral or axial skeleton lesions. In some occasions they could be the tumour debut. Most common localizations are in the mandible body and attached gingival. Most frequent strain of solid tumours is epithelial, and origin is lung, breast or liver in recent series, slightly variable depending on the geographical source and sex stratification. Multidisciplinary management could benefit the patient status and lead to more favourable outcomes, in terms of quality of life and function. There are exceptional cases of long-term survival.

\section{ACKNOWLEDGEMENTS}

To every member of the Head \& Neck Tumours committee of the Cruces University Hospital.

\section{CONFLICT OF INTEREST}

The authors declare no conflict of interest.

Preliminary results were presented in the "Congreso de Cirugía Oral e Implatología 17ed, Ibiza 2018" in Oral Comunication format: Lesiones metastásicas orales y maxilares (C. Prol, S. Ruiz-Oslé, S. Malaxetxebarria, A. Dolado, O. M. del Hoyo, L. Barbier).

\section{SCHOLARSHIP/FINANCIAL AID}

Neither scholarship nor financial aid were received.

\section{R E F E R E N E S}

1. Hirshberg A, Berger R, Allon I, Kaplan I. Metastatic tumors to the jaws and mouth. Head Neck Pathol. 2014;8(4):463-74. DOI: 10.1007/s12105-014-0591-z.
2. Hirshberg A, Shnaiderman-Shapiro A, Kaplan I, Berger R. Metastatic tumours to the oral cavity - pathogenesis and analysis of 673 cases. Oral Oncol. 2008;44(8):743-52. DOI: 10.1016/j.oraloncology.2007.09.012.

3. Ruiz-Osle S, Prol C, Lardies R, Gaafar A, Barbier L, Arruza A. Renal Cell Carcinoma metastases in the maxillofacial area: Case series. Arch Esp Urol. 2017;70(8):732-5.

4. Prol C, Ruiz-Osle S, Malaxetxebarria S, Álvarez J. Metastatic prostate adeno-carcinoma and Paget's bone disease of the mandible. Rev Osteoporos Metab Miner. 2018;10(1):37-40. DOI: 10.4321/S1889-836X2018000100006.

5. Shen M-L, Kang J, Wen Y-L, Ying W-M, Yi J, Hua C-G, et al. Metastatic Tumors to the Oral and Maxillofacial Region: A Retrospective Study of 19 Cases in West China and Review of the Chinese and English Literature. J Oral Maxillofac Surg. 2009;67(4):718-37. DOI: 10.1016/j.joms.2008.06.032.

6. Irani S. Metastasis to the Jawbones: A review of 453 cases. J Int Soc Prev Community Dent. 2017;7(2):71-81. DOI: 10.4103/jispcd. JISPCD_512_16.

7. D'Silva NJ, Summerlin DJ, Cordell KG, Abdelsayed RA, Tomich CE, Hanks CT, et al. Metastatic tumors in the jaws: a retrospective study of 114 cases. J Am Dent Assoc. 2006;137(12):1667-72. DOI: 10.14219/jada.archive.2006.0112.

8. Friedrich RE, Abadi M. Distant Metastases and Malignant Cellular Neoplasms Encountered in the Oral and Maxillofacial Region: Analysis of 92 Patients Treated at a Single Institution. Anticancer Res. 2010;30(5):1843-8.

9. Thiele OC, Freier K, Bacon C, Flechtenmacher C, Scherfler S, Seeberger R. Craniofacial metastases: A 20-year survey. J Craniomaxillofac Surg. 2011;39(2):135-7. DOI: 10.1016/j. jcms.2010.10.009.

10. Daley T, Darling MR. Metastases to the Mouth and Jaws: A Contemporary Canadian Experience. J Can Dent Assoc. 2011;77.b67.

11. Jham BC, Salama AR, McClure SA, Ord RA. Metastatic tumors to the oral cavity: a clinical study of 18 cases. Head Neck Pathol. 2011;5(4):355-8. DOI: 10.1007/s12105-011-0286-7.

12. Shin SJ, Roh JL, Choi SH, Nam SY, Kim SY, Kim SB, et al. Metastatic Carcinomas to the Oral Cavity and Oropharynx. Korean J Pathol. 2012;46(3):266-71. DOI: 10.4132/KoreanJPathol.2012.46.3.266.

13. McClure SA, Movahed R, Salama A, Ord RA. Maxillofacial Metastases: A Retrospective Review of One Institution's 15-Year Experience. J Oral Maxillofac Surg. 2013;71(1):178-88. DOI: 10.1016/j.joms.2012.04.009.

14. Servato JP, de Paulo LFB, de Feria PR, Cardoso SV, Loyola AM. Metastatic tumours to the head and neck: retrospective anal- 
ysis from a Brazilian tertiary referral centre. Int J Oral Maxillofac Surg. 2013;42(11):1391-6. DOI: 10.1016/j.ijom.2013.05.020.

15. Maschino F, Guillet J, Curien R, Dolivet G, Bravetti P. Oral metastasis: a report of 23 cases. Int J Oral Maxillofac Surg. 2013;42(2):164-8. DOI: 10.1016/j.ijom.2012.10.029.

16. Murillo J, Bagan JV, Hens E, Diaz JM, Leopoldo M. Tumors metastasizing to the oral cavity: a study of 16 cases. J Oral Maxillofac Surg. 2013;71(9):1545-51. DOI: 10.1016/j.joms.2013.03.017.

17. Owosho AA, Xu B, Kadempour A, Yom SK, Randazzo J, Ghossein $\mathrm{RA}$, et al. Metastatic solid tumors to the jaw and oral soft tissue: A retrospective clinical analysis of 44 patients from a single institution. J Craniomaxillofac Surg. 2016;44(8):1047-53. DOI: 10.1016/j.jcms.2016.05.013.

18. Lee YH, Lee JI. Metastatic carcinoma of the oral region: An analysis of 21 cases. Med Oral Patol Oral Cir Bucal. 2017;22(3):E359-E65. DOI: 10.4317/medoral.21566.

19. Liu Y, Vargo RJ, Bilodeau EA. Analytic survey of 57 cases of oral metastases. J Oral Pathol Med. 2018;47(3):275-80. DOI: 10.1111/ jop.12672.

20. Rao RS, Patil S, Sanketh D, Amrutha N. Metastatic tumors of the oral cavity. J Contemp Dent Pract. 2014;15(2):263-71.
21. Rosario Regalado Rd, Gallana Álvarez S, Creo Martínez T, Herce López J, Pereira Gallardo S. Lingual metastasis from renal carcinoma. Rev Esp Cir Oral Maxilofac. 2007;29(3):179-81.

22. Santamaria J, Garcia AM, Gil J, Barbier L. Metastasis of a malignant melanoma to the region of an impacted mandibular third molar: A case report. J Oral Maxillofac Surg. 1997;55(9):1003-6. DOI: 10.1016/s0278-2391(97)90079-3.

23. Ferreras Granado J, García-Rozado González Á, Gómez Oliveira G, Vázquez Mahía I, López-Cedrún Cembranos JL. Mandibular metastases of gastric adenocarcinoma: A case report. Rev Esp Cir Oral Maxilofac. 2007;29(5):319-23.

24. Diaz-Reverand SA, Naval-Gíaz L, Muñoz-Guerra MF, SastrePérez J, Rodríguez-Campo FJ, Gil-Diez JL. Management of medication-related osteonecrosis of the jaw according to the clinical grade: An analysis of 19 cases. Rev Esp Cir Oral Maxilofac. 2018;40(3):104-11. DOI: 10.1016/j.maxilo.2017.06.001.

25. Smith J, Birkeland AC, McHugh JB, Spector ME. Maxilla Osteonecrosis: a differential diagnosis in patients with metastatic cancer on bisphosphonates. J Case Rep Med 2016;5. DOI: 10.4303/jcrm/235969. 